\title{
Attacks Decline Conopomorpha cramerella Snell at Cocoa Plants Use Biological Agents, Bio-Pesticides, Light and Ultrasonic
}

\author{
Baharudin ${ }^{1, *}$ Dian Rahmawati ${ }^{1, *}$ Yudi $\operatorname{Irawan}^{1}$ Muhammad Alwi Mustaha ${ }^{1}$ Sarjoni $^{1}$ and \\ Rubiyo $^{2}$
}

\author{
${ }^{1}$ Assessment Institute of Agriculture Technology Southeast Sulawesi, \\ Prof Muh. Yamin Street No.89, Puuwatu, Kendari 93114 \\ ${ }^{2}$ Center for the Study and Development of Agricultural Technology Bogor \\ Jl. Tentara Pelajar No.10 Bogor 16114 \\ *Corresponding author.Email: bahar161060@yahoo.com,dian.sp27@yahoo.com
}

\begin{abstract}
Cocoa pod borer (Conopomorpha cramerella L.) is a major pest of cocoa, including in Southeast Sulawesi and is able to reduce yields up to $90 \%$, especially in the dry season. So far, farmers control these pests through the application of chemicals with high doses so that it has a negative impact on the environment. The aim of this research was to obtain a package of environmentally friendly $C$. cramerella pest control technology which was carried out at the center of Watarema Village, Lambuya District, Konawe Regency in 2019. The study was arranged using a randomized block design (RCBD) with 6 treatments, namely: (a). Beauveria bassiana, (b). Citronellal eleostreric myuric acid lauric acid, (c). Trichoderma asperellum, (d). A combination of garlic extract and clove oil, (e). Lighting + ultrasonic sound waves, and (f). lambda cyhalothrin thiametoxam as a control. All treatments were repeated 5 times on Sulawesi 1 cocoa clones, aged 10 years. Observation data were analyzed using analysis of variance and continued with the mean value test using Duncan's multiple range at the 0.05 level. The results of preliminary observations indicate the percentage of pest attacks at the study site ranged from $40-90 \%$. The results showed that the lighting treatment at night accompanied by the use of ultrasonic sound produced the lowest percentage and intensity of attacks, respectively $7.69 \%$ and $7.85 \%$ and were significantly different from controls, although not significantly different from other treatments. Decreasing the percentage and intensity of $C$. cramerella pests can improve the health of cocoa beans and fruit. This is able to increase the number of fruits and seeds, dry seed weight and weight per 100 seeds, seed yield, and cocoa productivity of $730.19-805.35 \mathrm{~kg} / \mathrm{ha}$ and reduce cocoa yield loss of $432.87-511.55 \mathrm{~kg} / \mathrm{ha}$.
\end{abstract}

Keywords—biological agents, Conopomorpha cramerella, biopesticides, light and ultrasonic

\section{INTRODUCTION}

Cocoa is one of the main commodities in the plantation sub-sector and is a contributor to foreign exchange for Indonesia. Plants are widely distributed in a number of areas, but the main centers are on the Sulawesi island, especially Southeast Sulawesi. Cocoa plant area in Southeast Sulawesi is 255.621 ha to 160.906 families whose livelihood head of this commodity (BPS Plantation, 2020) [1]. The majority of cocoa is cultivated through community plantation patterns and the remainder is cultivated through government and private plantations. At present the condition of cocoa plantations in the community is mostly classified as old age so that production and productivity are low.

National cocoa production mostly comes from Sulawesi Island, namely Southeast Sulawesi, South Sulawesi and Central Sulawesi (Zaenudin and Baon, 2004; Baharudin and Rubiyo, 2013) [2,3]. The national cocoa production and productivity are 652,396 tons and $0.2-0.8$ tons / ha / year, respectively. Specifically, in Southeast Sulawesi, cocoa production is 142,467 tons with a productivity of $0.4-0.6$ tons / ha (Baharudin and Asaad, 2017) [4]. The productivity is still relatively low compared to its potential to reach 2-3 tons / ha / year (Alvin, 1977; Wahyudi \& Rahardjo, 2008; Baharudin and Rubiyo, 2013) $[5,6,4]$. The low productivity of cocoa is partly due to the high attack of $C$. cramerella pests. These pests are found in the cocoa area (Supartha et al., 2008; Putra et al., 2011) [7,8] and specifically in Southeast Sulawesi, these pests have spread throughout the cocoa plantation area. In the larval stage $C$. cramerella pest attacks cacao fruit with a diameter of $8 \mathrm{~cm}$ and damages the development of seeds in the fruit. In this stage the larvae enter and damage the fruit, then the tissue percentage until the cocoa beans become sticky and harden.

Conopomorpha cramerella Report attack causes a decrease in production and an increase in crop costs. Neither the report Wardojo (1980) [10] and Wiryadiputra et al. (1994) [11] that this pest also causes loss of cocoa yield. The spread 
of C. cramerella attacks has developed throughout the world including Indonesia with different levels of investment severity so that the level of control is also different. According to Djunaedy (2009) [12], pest control generally uses high-dose chemical insecticides that are thought to cause environmental pollution and endanger living things, especially humans.

Using the Biopesticide such as citronella oil (Cymbopogon citratus) containing essential oils and eugenol in clove oil are effective to control C. cramerella pests. Other controls that are also classified as environmentally friendly are the use of biological agents such as Trichoderma asperellum and Beauveria bassiana. From a number of reports it is known that 1500 types of plants are potentially processed into plant-based pesticides because they have citral scents and compounds (Grainge \& Ahmed, 1988; Guenter, 1948) $[13,14]$. Citral and eugenol compounds are able to control C. cramerella pests. Bio pesticides are also known in addition to controlling pests, it can also control plant diseases (Istianto, 2009) [15].

As a result of these pests, the quality of national cocoa beans has decreased more than other cocoa producers. In the global era, quality competition is very tight, so that the results of Indonesia's cocoa bean exports suffer a lot of losses. The loss of Indonesian cocoa beans is due to the Automatic Detention by the US Food and Drug Administration (USFDA), whereby all exports of Indonesian cocoa beans before being dismantled are subject to automatic containment without prior inspection and immediately re-investigated.

An integrated and environmentally friendly agricultural system can produce raw materials with good and healthy quality standards, such as regulation of plant density, garden sanitation, pruning, fertilizing, frequent harvesting, utilization of biological agents and biopesticides (Lebe et al., 2008) [16]. Based on that description above, improvements in $C$. cramerella pest control through the application of plant-based pesticides, light regulation and the use of ultrasonic sound.

\section{MATERIALS AND METHODS}

Research has been carried out in Watarema Village, Lambuya Subdistrict, Konawe District, 2019. Materials used include productive side grafted cocoa (Sulawesi clone 1), biological agents (Beauveria bassiana and Trichoderma asperellum), garlic extract, eleostreric lauric acid citronellal, eugenol, and night lighting plus ultrasonic sound waves and chemical insecticides namely lambda cyhalothrin thiametoxam. Tools used are knapsack sprayers, measuring cups, scissors, pruning shears, machetes, plastic buckets, scales, hand counters, plastic bags and others.

The study was arranged in a Randomized Block Design with six types of treatments and repeated five times, so that there were 30 research units. Each treatment uses 15 plants, so there are 450 plants as observation units. The treatments are as follows:
A. Beauveria bassiana

B. Citronella Oil eleostearic lauric acid

C. Trichoderma asperellum

D. Combination of garlic extract formulation and clove oil

E. Lighting + ultrasonic sound waves

F.Chemical pesticide, lambda cyhalothrin thiametoxam as a control

Control of $C$. cramerella pests when many fruits with a size of $9-10 \mathrm{~cm}$ based on the attack percentage $20 \%$ for biological agents (B. bassiana, and Trichoderma spp. Southeast Sulawesi) and 30\% for Biopesticide and chemical fungicides (Biotris, garlic extract, clove oil and citronella, as well as lighting + ultrasonic sound waves and lambda cyhalothrin thiametoxam spray volume for antifitopathogen 107-109 spores / $\mathrm{ml}$ water and Biofungicide (clove oil and citronella) $5 \mathrm{ml} /$ liter water, and chemical insecticide $5 \mathrm{cc} /$ liter liter of water spraying 2 times with an interval of two weeks or every 10-15 days. Spraying targets are cocoa pods and all parts of the plant affected, and the soil is applied evenly in the morning or evening.

Observation of $C$. cramerella pest intensity for each replication was taken 180 samples and cocoa beans randomly. According to Lim (1992) [17] and Sulistyowati (2008) [18], C. cramerella attack rates can be categorized into severe, moderate and mild attacks (Table 1).

Table 1. Categories of C. cramerella pests

\begin{tabular}{ccc}
\hline $\begin{array}{c}\text { Categories and } \\
\text { scores }\end{array}$ & $\begin{array}{c}\text { Attack } \\
\text { rate }\end{array}$ & Criteria \\
\hline Healthy and 0 & $0 \%$ & Seeds are not sticky \\
Lightweight and 1 & $<10 \%$ & Sticky seeds \\
Medium and 2 & $10-$ & Sticky seeds \\
& $50 \%$ & \\
Weight and 3 & $>50 \%$ & Sticky seeds \\
\hline
\end{tabular}

1) The percentage of C. cramerella pests is calculated using the formula:

$$
\mathrm{P}=[(\mathrm{a}) /(\mathrm{a}+\mathrm{b})] \times 100 \%
$$

Information:

$\mathrm{P}=$ percentage of $C$. cramerella pests in cocoa pods

$\mathrm{a}=$ Number of cocoa pods infected by pests $\mathrm{C}$. cramerella

$\mathrm{b}=$ Number of healthy cocoa pods

2) The intensity of $C$. cramerella pest is calculated using the formula:

$$
\mathrm{I}=[(1 * \mathrm{R})+(3 * \mathrm{~S})+(9 * \mathrm{~B}) /(9 * \mathrm{~A})] * 100 \%
$$

Information:

$\mathrm{I}=$ intensity of $C$. cramerella pest attack on cocoa pods 
$\mathrm{R}=$ Number of cocoa pods with mild $C$. cramerella pest

$\mathrm{S}=$ Number of cacao attacked by $C$. cramerella

$\mathrm{B}=$ Number of cocoa pods attacked by $C$. cramerella

$\mathrm{A}=$ Total number of cacao fruits observed

3) The percentage loss of cocoa yield is calculated based on the equation according to Wardani et al. (1997) [19]:

$$
\mathrm{Y}=-0,0210+0,1005 \mathrm{X}
$$

Information:

$\mathrm{Y}=$ Loss of yield on cacao

$\mathrm{X}=$ Intensity score of $C$. cramerella pest on cocoa

4) Intensity score of C. cramerella pest on cocoa using the formula:

$$
\mathrm{X}=[(0 * \mathrm{Sh})+(1 * \mathrm{R})+(3 * \mathrm{~S})+(9 * \mathrm{~B})] /(\mathrm{JB})
$$

5) Intensity of C. cramerella pests on cocoa using the formula:

$$
\mathrm{I}=[(1 * \mathrm{R})+(3 * \mathrm{~S})+(9 * \mathrm{~B}) /(9 * \mathrm{~A})] * 100 \%
$$

Information:

$\mathrm{I}=$ intensity of $C$. cramerella pest attack on cocoa pods $\mathrm{X}=$ Intensity score of $C$. cramerella pest on cocoa $\mathrm{Sh}=$ Number of healthy cacao

$\mathrm{R}=$ Number of cocoa pods with mild $C$. cramerella pest $\mathrm{S}=$ Number of cacao attacked by $C$. cramerella

$\mathrm{B}=$ Number of cocoa pods attacked by $C$. cramerella $\mathrm{JB}=$ Total number of cacao fruits observed

The yield loss equation (Y) above is multiplied by $100 \%$ to find out the percentage of yield loss due to $C$. cramerella. The results of the percentage loss in each treatment compared with the control. Rainfall data as supporting data for 5 years (years 2012-2016). Rainfall data are used to link climate conditions with the development of $C$. cramerella pests. Beauveria bassiana biological agents were obtained from the Field Laboratory of the Plantations and Horticulture Office of the Southeast Sulawesi Province and Citronella Oil eleostearic lauric acid or citronella oil from the Research Institute for Industrial Plants and Refresher Bogor. Early warning system is preceded by observation of $C$. cramerella pest after $>10 \%$ / tree. C. cramerella pest attacks are suppressed below the tolerance threshold, controlled with biological agents, biopesticides, ultrasonic sound waves and lambda cyhalothrin thiametoxam to reduce the use of chemical insecticides. This is done on a limited basis to improve the efficiency of negative impacts on the environment. Reducing loss of cocoa yield to reduce environmental damage by being environmentally friendly. Observation data were analyzed by analysis of variance using the SAS program, if the results of variance showed real influence, followed by the middle value test using Duncan's multiple range test.

\section{RESULTS AND DISCUSSION}

\subsection{General Characteristics of Location}

The condition of cocoa plantations in Watarema Village is lowland. The average plant condition is 10 years old. Cacao plants have been spliced side by side and shoot top by Sulawesi clones 1 . The rainfall conditions at the location for five years (2015-2019), is experienced variations. As with other locations, there is a long dry season in Southeast Sulawesi in 2019, as a result the supply to meet crop needs is relatively limited. Rainfall in 2015 - 2019 starts from January to March (8-240 mm), starts to increase in April, peaks in May and June $(360 \mathrm{~mm})$ and rainfall decreases in August to December. Rainfall is very high in January to June 2019 than the condition of low rainfall greatly affects the level of $C$. cramerella pest attack $50-90 \%$ on cocoa plants. Institutional and private actors can use our work to scale out locally conceived interventions to alleviate impacts from drought, heat and erratic rainfall (Bunn et al., 2019) [20]. CPB attack is very high in cocoa plants, both in conditions of low and high rainfall levels.

Estimated rate of $C$. cramerella pests on cocoa plants is affected by rainfall conditions for five years (Figure 1).

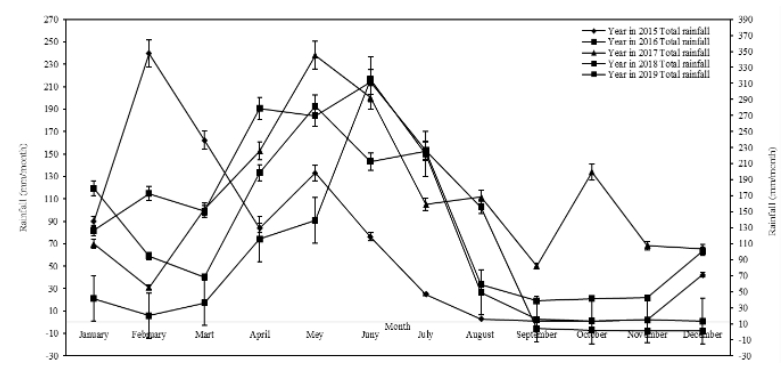

Figure 1. Rainfall data for five years (2015-2019) at the study site

\subsection{Percentage and intensity of Conopomorpha cramerella pest attacks}

In preliminary observations it is known that the percentage and intensity of $C$. cramerella pests in cocoa before research is quite high between 40-90\%. After treatment application, the percentage of attacks decreased from 7.69 to $23.65 \%$ and the intensity of attacks from 7.85 to $18.25 \%$. The decrease in attack percentage and intensity of $C$. cramerella attack showed significant differences in the treatment of citronellal eleostreric myuric acid, Trichoderma asperellum, garlic extract + clove oil, Beauveria bassiana and the use of lighting + ultrasonic sound waves with lambda cyhalothrin thiametoxam treatment. The lowest attack percentage and intensity of PBK pest attack in the lighting treatment + ultrasonic sound waves (Figure 2). 


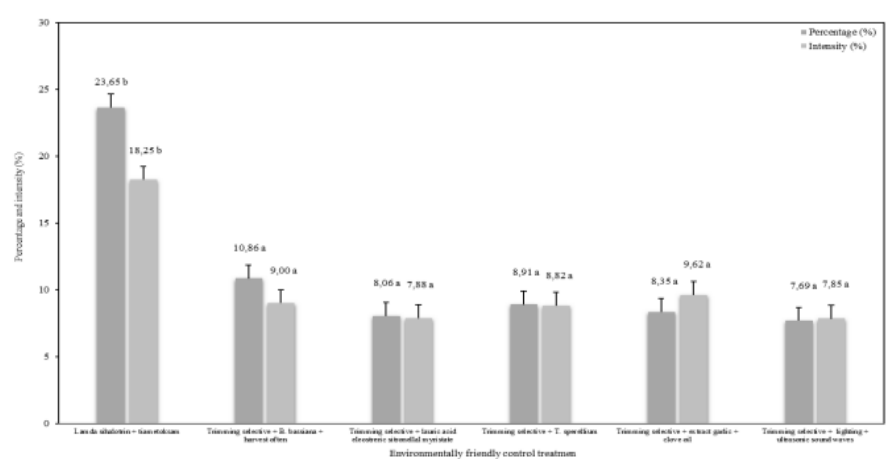

Figure 2. Percentage and intensity of $C$. cramerella pest attacks in various treatments

The decrease attack of $C$. cramerella pests with the application of biological agents and biopesticides, application in October-December. Increased $C$. cramerella can cause a decrease in the number of cocoa beans and fruit, yield quality, productivity and an increase in cocoa yield loss is quite high. The development of the percentage and intensity $C$. cramerella pests before being controlled with biological agents and biopesticides $82.41 \%$ and $71.21 \%$ and after controlling decreased $4.73 \%$ and $5.12 \%$ and were classified as very low. The high percentage and intensity of attacks, because supporting conditions of the cocoa plants such as branches, cover each other, and are highly favored for the development of $C$. cramerella pests. In the application of cocoa plants, biological agents and pesticides need to be do on time and continuously. The results of pruning + lighting + ultrasonic sound wave research (Nurmansyah, 2011; Wayan Laba et al. 2011) [21,22], treatment of citronella, eugenol, azadirachtin concentration of $5 \mathrm{ml} / 1$, reducing cocoa pod damage due to $C$. cramerella attacks (Figures 3 and 4).

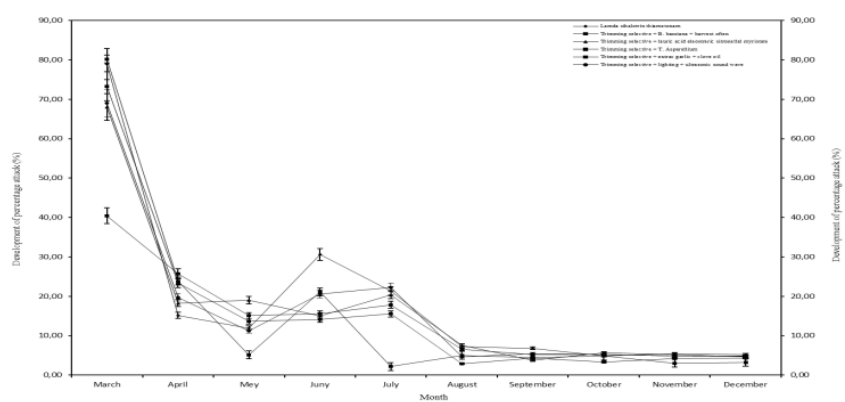

Figure 3. Development of the percentage of $C$. cramerella pests during 9 months at the study site

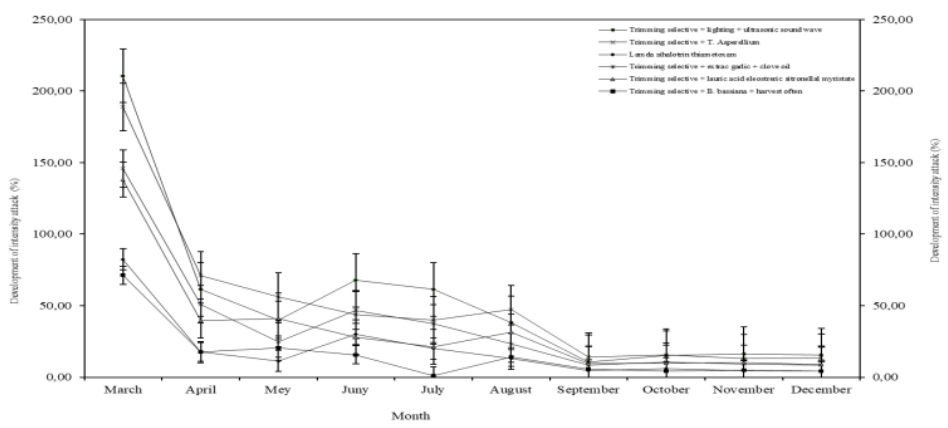

Figure 4. Development of $C$. cramerella pest intensity for 9 months at the study site

\subsection{Components of yield and Cocoa Outcomes}

The number of fruits and weight per 100 cocoa beans, except the number of seeds and weight of dried seeds per fruit in the treatment of biological agents and biopesticide, light and ultrasonic sound showed significant differences. The highest number of fruits, number of seeds, and weight per 100 seeds at night light is accompanied by the use of ultasonic sound waves, while the lowest is the treatment of chemical pesticides. The increasing productivity cocoa farmers while maintaining environmental services, is the leading cocoa production (Gockowski et al., 2013; Schroth et al., 2017) $[23,24]$. The use of environmentally friendly technology packages can increase the number of fruit, and cocoa productivity.

Table 2. Number of fruits, number of seeds and weight of dried seeds per fruit, and weight per 100 cocoa beans in various $C$. cramerella pest control

\begin{tabular}{|c|c|}
\hline Treatment & Average \\
\hline \multicolumn{2}{|c|}{ 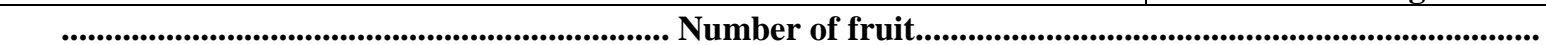 } \\
\hline Chemical pesticide, lambda cyhalothrin thiametoxam as a control & $62,13 \mathrm{c}$ \\
\hline Beauveria bassiana & $68,53 \mathrm{c}$ \\
\hline Citronella Oil eleostearic lauric acid & $67,04 \mathrm{c}$ \\
\hline Trichoderma asperellum & $78,42 \mathrm{ab}$ \\
\hline Combination of garlic extract formulation and clove oil & $82,04 \mathrm{a}$ \\
\hline Lighting + ultrasonic sound waves & 83,28 a \\
\hline \multicolumn{2}{|c|}{ 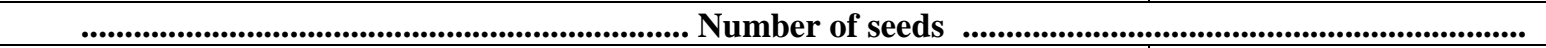 } \\
\hline Chemical pesticide, lambda cyhalothrin thiametoxam as a control & $38,01 \mathrm{a}$ \\
\hline Beauveria bassiana & $38,00 \mathrm{a}$ \\
\hline Citronella Oil eleostearic lauric acid & $38,45 \mathrm{a}$ \\
\hline
\end{tabular}




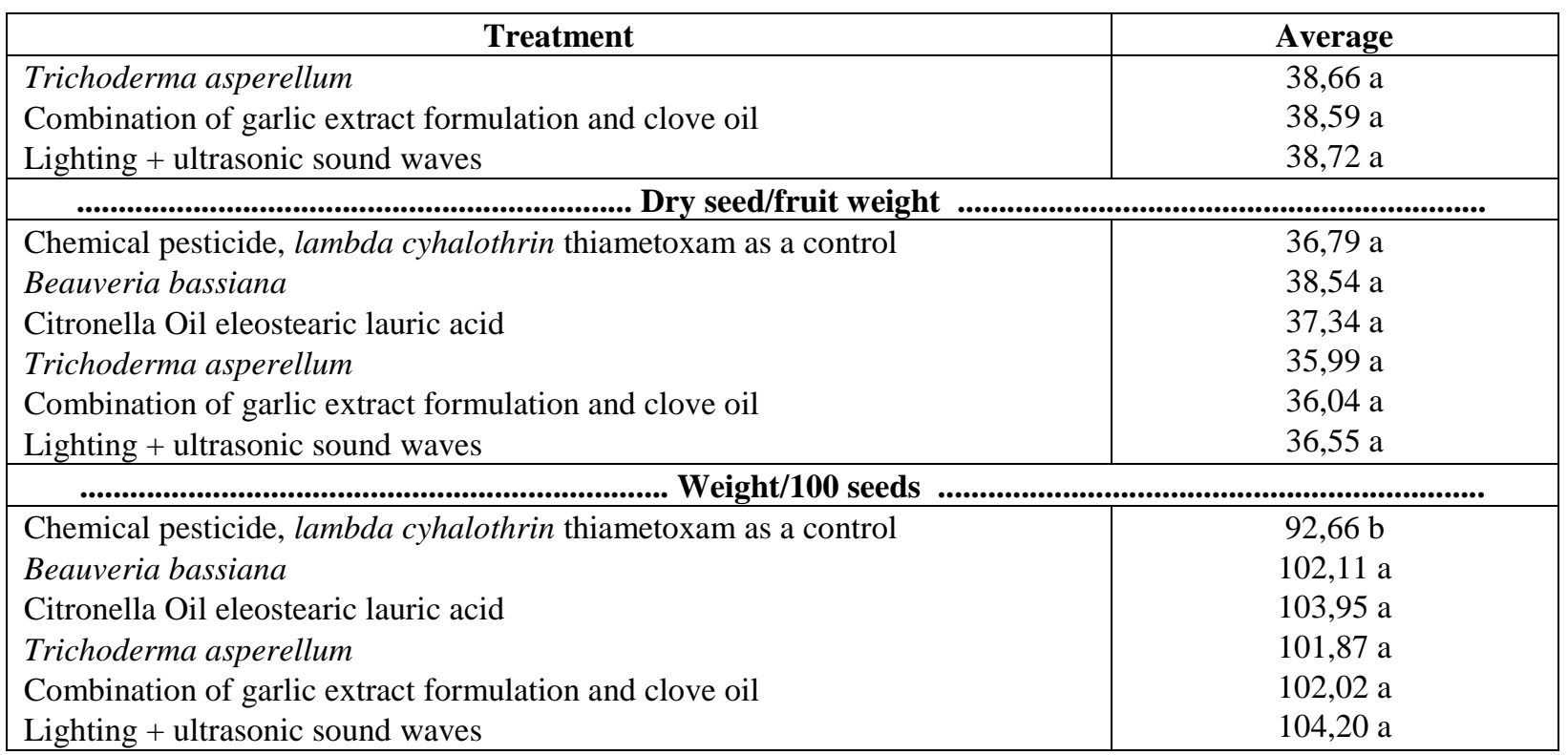

Note: The numbers followed by the same letter in the same column are not significantly different according to Duncan's distance test $95 \%$ confidence level

\subsection{Rendement, Yield, loss and productivity of Cocoa}

The yield, yield loss and productivity of cocoa by the treatment of biological agents and biopesticides show variation the real differences with controls. Yield and productivity and yield loss of cocoa beans are highest in the lighting treatment at night accompanied by the use of ultrasonic sound waves, while the lowest is in the treatment of chemical pesticides (Figure 5). The low yield and productivity, as well as the high yield loss caused by the high attack of $C$. cramerella pests and markedly affected the decline in yield quality. Finally, quantity of pesticide, proportion of hybrid cocoa plants and number of trainings received by farmers significantly reduced yield gap in the wet zone (Abdulai et al., 2020) [25]. Therefore, to reduce the yield reduction, yield loss and productivity of cocoa, it is important to control the use of biological agents and plant-based pesticides in a timely manner and the use of lighting at night accompanied by the use of ultrasonic sound waves.

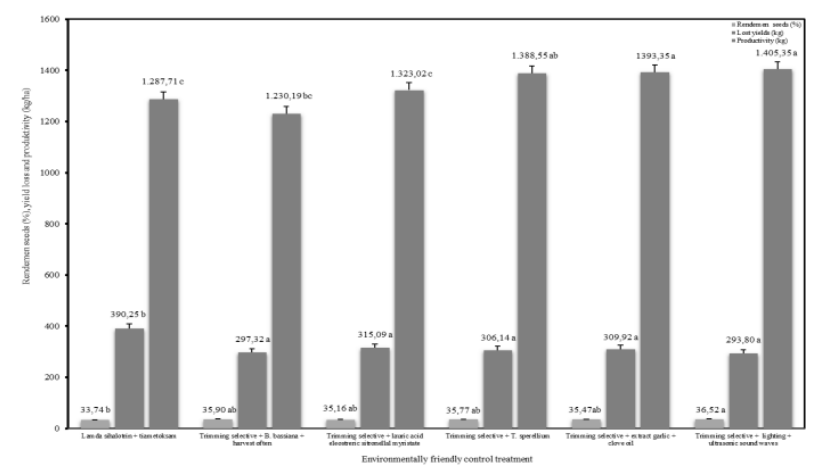

Figure 5. Yield, yield loss and cocoa productivity in various C. cramerella pest controls

\section{CONCLUSION}

a. Percentage and intensity of $C$. cramerella pest attack before treatment is $40-90 \%$, but after application of biological agents, biopesticides and night lightings and accompanied by the use of ultrasonic sound waves, the attack percentage becomes $23.65-7.69 \%$ or decreased by $16.35-82.31 \%$ and the intensity of attacks was 18.25 $7.85 \%$ or decreased by $21.75-80.15 \%$.

b. The development of the percentage and intensity of $C$. cramerella pests before treatment was $82.41 \%$ and $71.21 \%$, but after application of biological agents, biopesticides, night light trap and use of ultrasonic sound waves, the percentage and intensity of attacks decreased to $4.73 \%$ and $5.12 \%$ (meaning relatively mild).

c. The use of biological agents, biopesticides and nighttime lighting and accompanied by the use of ultrasonic sound waves is able to produce the number of fruits and seeds, dry weight and weight per 100 seeds, seed yield, cocoa productivity $730,19-805.35 \mathrm{~kg} / \mathrm{ha}$, more high compared to the application of chemical pesticides (control).

\section{AUTHORS' CONTRIBUTIONS}

Scientific publication entitled "Attacks Decline Conopomorpha cramerella Snell at Cocoa Plants Use Biological Agents, Bio-Pesticides, Light and Ultrasonic” All authors are the main contributors in conducting the research and writing the scientific articles.

\section{ACKNOWLEDGMENTS}

Thanks to all those who have supported the research. This research received funding from the DIPA AIAT Southeast Sulawesi 2019. Cocoa farmers in Watarema 
Village, Lalembu District, Konawe Regency, Southeast Sulawesi. which facilitates a cocoa plantation as a research location. and thanks to several technical field staff for their support and participation in the implementation of data collection in the field.

\section{REFERENCES}

[1] BPS of Southeast Sulawesi Province. 2020. Southeast Sulawesi in Figures 2020.

[2] Zaenudin and J. B. Baon, 2004. Prospects for National Cocoa One Decade (2005-2014) In The Future. 2004 Cocoa Symposium Jogjakarta, 4-5 October 2004. Indonesian Coffee and Cocoa Research Center, Jember 2004, 1-10.

[3] Baharudin and Rubiyo, 2013. Effect of Seed Treatment and Planting Media on the increase in vigor of hybrid cocoa seedlings. Southeast Sulawesi Agricultural Technology Research Institute and Industrial and Refreshing Crops Research Institute. RISTRI Bulletin. 4 (1): 27-38

[4] Baharudin and Asaad, M. 2017. Control effectiveness of Phytophthora palmivora with biological agents to increase cocoa productivity. Plantation Tower 85 (1), 9-18 p-ISSN: 0215-9318 / e-ISSN: 1858-3768.

[5] Alvin, P.De.T. 1977. Ecological Determinants of Cocoa Yield. Procedings V. International Cocoa Research Conference, Ibadan Nigeria, 25-38.

[6] Wahyudi, T and P. Rahardjo. 2008. History and Prospects. Complete Guide to Cocoa. Management and Agribusiness from Upstream to Downstream, 1126.

[7] Supartha, I. W., I. W. Susila, I. M. Mastika. 2008. Demonstration Plot of Borer Pest Control and Cocoa Pod Rot in an Integration, Collaboration between the Bali Provincial Plantation Office and the HPT Department of Fak. Agriculture, Udayana University, Denpasar. Bali Provincial Plantation Office.

[8] Putra, I. G. A. P, N. L. Watiniasih \& N. M. Suartini. 2011. Inventaritation of Insects in the Cacao Pplantation (Theobroma cacao) of Plant Protection Laboratory Bedulu, Blahbatu District, Gianyar Regency, Bali. Journal Biological, XIV (1): 19-24.

[10] Wardojo, S. 1980. The cocoa pod borer moth - a major hindrance to cocoa development. Indonesian Agricultural Research and Development Journal, 2:24

[11] Wiryadiputra.S., E. Sulistyowati, A.A. Prawoto (1994) Pest Control Techniques for Cocoa Pod Borer Workshop on CPB Pest Management in Indonesia. Regional Seminar on Agricultural Technology Innovation, supporting the North Sulawesi Province Agricultural Development Program. Jember, 165174.

[12] Djunaedy, A. 2009. Biopesticides as an environmentally friendly control of plant pests. Embryo, 6 (1): 88-95.
[13] Grainge, M. and S. Ahmed. 1988. Handbook of Plants with Pest Control Properties. John Wiley and Sons.470 pp.

[14] Guenther, E. 1948 The Essential Oil Vol. 4 (Essential Oil, Ketaren translation, subject: Lemongrass Kitchen). University of Indonesia Press. Jakarta.

[15] Istianto, M., (2009), Utilization of Essential Oils, Alternative Technology for the Control of Environmentally Friendly Fruit Pest Organisms, Tropical Fruit Research Institute, West Sumatra.

[16] Lebe, I., A. Anshary and M. H. Toana. 2008. Effect of Urea Fertilization and Sanitation on Intensity of Attack on Cocoa Pod Borer (Conopomorpha cramerella Snell.). Journal of Agrisains, 9 (2): 81-88.

[17] Lim, G. T. 1992. Biology, Ecology \& Control Of Cocoa Pod Borer, Conopomorpha cramerella pp.85_100. In. Keane P.J. and C.A.J. Putter. (eds.) Cocoa pest and Diseases Management in Sotheast Asia and Australasia. FAO Plant Production and Protection Paper. FAO United Nations. Rome.

[18] Sulistyowati, E. 2008. Pest Control. Complete Guide to Cocoa. Agribusiness Management from Upstream to Downstream. Self-Help Spreader, 148-151.

[19] Wardani, S; H. Winarno \& E. Sulistyowati. 1997. Estimation model of yield loss due to cocoa pod borer attack. Pelita Perkebunan, 13: 33-39

[20] Bunn, C., L. Peter, A. Quaye, M. Sander, M. R..A. Noponen and M Lundy. 2019. Recommendation domains to scale out climate change adaptation in cocoa production in Ghana. Journal Agricultural Systems. Elsevier. 1-12 p.

[21] Nurmansyah. 2011. The effectiveness of lemongrass against cocoa pod sucker Helopeltis natonii. Littro's Bulletin, 22 (2): 205-2013.

[22] Wayan Laba, I., M. Willis, Rohimatun, Ahyar, N. Tarigan, C. Sukmana. 2011. Fruit Borer (Conophomorpa cramerella) Pest Control> 50\% and Fruit Rot Disease (Phytopthora palmivora) $>30 \%$ in Cocoa. Bogor Balitro Research Technical Report. 281-189.

[23] Gockowski, J., V. Afari-Sefa, D.B. Sarpong, 2013. Improving the productivity and income of Ghanaian cocoa farmers while maintaining environmental services: what role for certification. Int. J. Agric. Sustain. 11, 331-346.

[24] Schroth, G., LÃåderach, P., Martinez-Valle, A.I., Bunn, C., 2017. From site-level to zoneal adaptation planning for tropical commodities: cocoa in West Africa. Mitig. Adapt. Strateg. Glob. Chang. 22, 903927

[25] Abdulai, I., M. P. Hoffmann, L. Jassogne, R. Asare, S. Graefe, H. Hang Tao, S. Muilerman, P. Vaast, P. Van Asten, P. Laderach and R. P. Rotter. 2020. Variations in yield gaps of smallholder cocoa systems and the main determining factors along a climate gradient in Ghana. Journal Agricultural Systems. Elsevier. 1-8 p. 